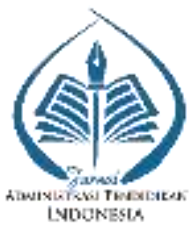

JURNAL ADMINISTRASI PENDIDIKAN INDONESIA VOL. 11 No. 1. Th. $2020(11-20)$

(Print ISSN 2613-9561 Online ISSN 2686-245X)

Tersedia online di http://ejournal-pasca.undiksha.ac.id/index.php/jurnal_ap

\title{
PENGARUH PENDIDIKAN KARAKTER BERBASIS KEARIFAN LOKAL TRI KAYA PARISUDHA UNTUK MEWUJUDKAN BUDAYA CERDAS DALAM PERLINDUNGAN ANAK SEKOLAH DASAR
}

\author{
Received: 12 Mei 2020; Revised: 7 Juli 2020; Accepted; 10 Juli 2020 \\ Permalink/DOI: https://doi.org/10.23887/japi.v11i1.3156
}

\author{
I.M. Ariasa', A.A.G. Agung ${ }^{2}$, I.N. Natajaya ${ }^{3}$ \\ 1,2,3Program Studi Administrasi Pendidikan, Universitas Pendidikan Ganesha Singaraja, \\ e-mail: ariasa.3@undiksha.ac.id1', agung2056@undiksha.ac.id², nyoman.natajaya@undiksha.ac.id³
}

\begin{abstract}
Abstrak
Penelitian bertujuan untuk mengetahui pengaruh pendidikan karakter berbasis kearifan lokal tri kaya parisudha untuk mewujudkan budaya cerdas dalam perlindungan anak. Jumlah populasi dalam penelitian ini adalah 8 kelas siswa kelas 5 yang terdiri dari 300 siswa SD di desa Mas kecamatan Ubud Kabupaten Gianyar. Penentuan sampel digunakan kluster random sampling. Terpilih kelas 5 SD N 5 Mas sebagai kelas eksperimen dan kelas 5 SD N 8 Mas sebagai kelompok kontrol. Pengumpulan data dengan kuesioner. Analisis data digunakan teknik analisis statistik deskriptif dan statistik inferensial uji t $(t$-test). Hasil analisis data diperoleh bahwa budaya cerdas siswa yang dibelajarkan dengan pendidikan karakter berbasis kearifan lokal tri kaya parisudha lebih tinggi daripada siswa yang dibelajarkan dengan tanpa pendidikan karakter berbasis kearifan lokal (skor rerata kelompok eksperimen $=183,05$ skor rerata kelompok kontrol $=168,17$ dan t $=6,671$ ). Disimpulkan bahwa terdapat pengaruh yang signifikan pendidikan karakter berbasis kearifan lokal tri kaya parisudha terhadap budaya cerdas siswa SD di desa Mas, kecamatan Ubud, Gianyar.
\end{abstract}

Kata Kunci: Pendidikan Karakter; Kearifan Lokal; Budaya Cerdas

\begin{abstract}
This study aims to determine the effect of tri kaya parisudha based local wisdom based character education to realize smart culture in child protection. The population in this study was 300 students at SD in Mas village Ubud district Gianyar regency. The determination of the sample used cluster random sampling. With this sampling technique, grade 5 SD N 5 Mas was selected as the experimental class and grade 5 SD N 8 Mas as the control group. The data was collected by Non-Test Method with the instrument in the form of a questionnaire that was to measure intelligent cultural variables. The data analysis used descriptive statistical analysis techniques and inferential statistical ttest. The results of data analysis showed that the smart culture of students who were taught with character education based on local wisdom tri kaya parisudha was higher than students who were taught with no character education based on local wisdom based on wisdom tri kaya parisudha (mean score of experimental group $=183.05$ control group average score $=168,17$ and $t=6.671$ ). It was concluded that there was a significant influence of tri kaya parisudha based local wisdom on the intelligent culture of elementary school students in Mas village, Ubud district, Gianyar regency.
\end{abstract}

Keywords: Character Education; Local Wisdom; Smart Culture 


\section{PENDAHULUAN}

Pendidikan nasional adalah bagian yang tidak bisa kita pisahkan dengan kegiatan pembangunan yang dilakukan pemerintah untuk mengamalkan Pancasila. Pendidikan secara nasional juga mempunyai peran yang penting untuk penjaminan kelestarian dari sebuah pembangunan. Pendidikan adalah suatu proses untuk bisa memberi pengaruh pada siswa supaya bisa beradaptasi dengan baik pada lingkungan. Melalui hal tersebut, diharapkan akan bisa menghasilkan perubahan pada diri individu yang memberi peluang untuk penyaluran pada pembangunan bangsa. Pada proses memenuhi tuntutan global pada era globalisasi yang sudah merubah dunia pada segala sisi hidup manusia termasuk di dalamnya aspek ekonomi, oleh karenanya pendidikan cenderung memberi penekanan pada pembentukan sumber daya manusia yang memiliki kualitas. Pembentukan sumber daya manusia (SDM) yang berkualitas tidak mudah, oleh karenanya begitu banyak hal yang wajib untuk dikerjakan guna mewujudkan hal tersebut khusus bagi dunia pendidikan, hal tersebut sangatlah sulit sehingga diperlukan sebuah pendidikan yang berkualitas yang didukung dengan berbagai sistem dan alat yang memadai untuk menunjang agar terciptanya pendidikan yang juga berkualitas.

Pada aktivitas bidang pendidikan ini masih sering ditemui banyak masalah, salah satunya yaitu masalah karakter para siswa contohnya masih banyak terjadi kasus kekerasan terhadap anak seperti; beredar foto dan video porno pada kalangan pelajar, marak terjadi pelecehan maupun kekerasan seksual bahkan menjurus pada prilaku seks bebas pada anakanak maupun remaja, serta kasus kekerasan antar sesama siswa. Tidak hanya itu, sekelompok anak-anak remaja saling berdebat beradu pendapat di sosial media mengenai kasus kekerasan terhadap anak-anak perempuan yang berkelahi atau tepatnya menganiaya temannya di ruang publik dan direkam dengan alat perekam smartphone dan menayangkan lewat berbagai media sosial. Dalam media online dan cetak, juga banyak memberitakan cukup banyak ada kejadian anak meninggal akibat mengalami kecelakaan karena belum cukup umur dan siap mental dalam berkendaraan di jalanan umum. Berdasarkan pemaparan di atas menunjukan bahwa pendidikan yang selama ini sudah berjalan belum bisa untuk memperbaiki karakter siswa. Dunia pendidikan disibukkan dengan melatih siswa menjawab soal secara sempurna dengan tidak mencari solusi pendidikan seperti apa yang bisa melakukan perubaham karakter pada siswa. Kita bisa bangga melihat generasi muda secara terampil bisa menyelesaikan soal ujian tapi tidak mempunyai karakter sesuai harapan.

Anak usia sekolah dasar (SD) merupakan masa anak tumbuh dan berkembang dengan lebih banyak meniru orang dewasa. Karakter anak usia SD lebih mudah dibentuk dibandingkan usia anak berikutnya. Oleh karenanya, pendidikan karakter sangat penting ditanamkan sejak anak usia dini termasuk usia SD. Pendidikan karakter seperti yang sudah dipaparkan di atas, wajib bisa dijalankan supaya dengan mudah untuk diterapkan di sekolah dasar. Supaya pendidikan karakter itu mudah untuk diterapkan oleh masyarakat, maka diperlukan strategi yang tepat untuk mengkolaborasikan antara pendidikan dengan kearifan lokal yang dimiliki masing-masing daerah. Pemberdayaan sumber pendidikan karakter dari kearifan lokal Bali bisa ditempuh dengan melakukan pendekatan diri peserta didik terhadap budaya sekitar. Melalui ini, peserta didik tidak akan merasakan keterasingan dengan budaya di sekitrnya. Hal ini bisa menghasilkan penguatan diri sebagai seorang manusia yang punya ciri khas apabila dibandingkan dengan yang lain. Pendidikan karakter bisa dikerjakan dengan merumuskan visi dan misi serta tujuan pembelajaran di sekolah. Selanjutnya, pendidikan karakter yang digabungkan dengan kearifan lokal Bali bisa diberi kemasan pada berbagai model aktivitas dan kreativitas ekstrakulikuler dan kulikuler. Pada penerapannya, sangat penting untuk dilakukan evaluasi diri guna meninjau berhasil tidaknya penerapan pendidikan karakter yang ada di sebuah sekolah. Sehubungan dengan penerapan pendidikan karakter pada kegiatan kurikuler bisa diterapkan lewat konsep tri kaya parisudha, yang bisa diterapkan pada kegiatan mesatua sambil melajah (belajar sambil bercerita), melajah sambil meplayanan (belajar sambil bermain), melajah sambil megending (bermain sambil bernyanyi) dan melajah sambil megae (belajar sambil bekerja).

Tahapan pada pembelajaran yang digunakan oleh guru di sekolah bisa dikolaborasikan dengan konsep tri kaya parisudha. Secara etimologi tri kaya parisudha (bahasa Sanskerta) 
dari kata tri berarti tiga, kaya berarti perbuatan/prilaku dan pansudha berarti (amat) disucikan. tri kaya parisudha dapat disimpulkan sebagai tiga perbuatan/prilaku suci yang terdiri dari Manacika (berpikir yang bersih dan suci), Wacika (berkata yang baik, sopan dan benar), dan Kayika (berbuat yang jujur, baik dan benar). Ketika konsep tri kaya parisudha bisa dikolabirasikan pada setiap langkah-langkah pembelajaran yang dilakukan oleh guru, maka akan melahirkan generasi muda yang mampu berpikir secara bersih dan jernh. Dengan pikiran yang jernih maka tutur kata yang dikeluarkan oleh siswa akan menjadi jujur, baik, sopan, dan perbuatan yang dilakukanpun akan menjadi positif, sehingga akan melahirkan generasi muda yang berkarakter positif.

Pendidikan karakter tidak hanya mempunyai kaitan dengan masalah benar atau salah, tetapi bagaimana memberi penanaman kebiasaan (habit) berkaitan dengan hal yang baik pada kehidupan, sehingga anak bisa mempunyai kesadaran dan memahami dengan baik dan memiliki rasa peduli serta komitmen untuk melakukan penerapan kebaikan pada aktivitas keseharian, dengan ini orang yang mempunyai karakter bisa memberi respons keadaan dengan bermoral, yang wujudnya ada pada gerak nyata lewat sikap yang baik, jujur, ikhlas, dan mempunyai tanggung jawab, dan juga hormat pada orang lain (Mulyasa, 2011). Pada proses membentuk karakter pada anak lewat membiasakan dengan kearifan lokal tri kaya parisudha, diharapkan mampu memberikan konsep pada anak pentingnya karakter tersebut. Dampaknya, hal-hal yang menuju pada diskriminasi, yang berbau pelecehan anak atau bentuk-bentuk kekerasan terhadap anak lainnya bisa dikurangi atau bahkan bisa dihindari. $\mathrm{Hal}$ ini akan merujuk pada kepentingan terwujudnya perlindungan anak yang lebih optimal. Karakter anak yang baik akan membentuk lingkungan yang baik, jika lingkungan tersebut baik. Ketika lingkungan tersebut baik, maka perlindungan terhadap anak pun dapat diwujudkan secara optimal juga.

Desa Mas merupakan sebuah desa wisata budaya yang sudah terkenal, baik itu bagi wisatawan Domestik maupun Manca Negara. Desa yang terletak di kecamatan Ubud, kabupatan Gianyar ini menghasilkan barang kerajinan seni, seperti seni patung, ukiran kayu dan berbagai jenis karya seni lainnya. Hasil karya kerajinan seni bisa ditemui di sepanjang jalan desa Mas yang dikemas dengan sangat menarik oleh artshop-artshop yang yang sekaligus menjual barang-barang kerajinan tersebut. Para pengukir, pematung dan pemahat yang ada di desa Mas tidak akan sulit untuk memasarkan hasil karyanya, karena letak desa Mas yang berada di jalur utama menuju berbagai obyek wisata terkenal yang ada di Gianyar. Masyarakat desa Mas harus bisa mempertahankan berbagai seni budaya yang menjadi ciri khas warisan leluhur, sehingga budaya tersebut tidak akan tergeser oleh budaya-budaya luar. Generasi muda desa Mas diharapkan nantinya bisa untuk ikut menjaga dan mempertahankan budaya tersebut, sehingga mampu bersaing di era abad 21 serta mampu menghadapi tantangan revolusi industri 4.0 tanpa melupakan budaya warisan lelulur yang agung. Salah satu strategi untuk mampu mempertahankan semua hal tersebut adalah melalui dunia pendidikan. Salah satu point penting yang harus diperhatikan oleh dunia pendidikan adalah bagaimana kita bisa membentuk karakter bagi para generasi muda yang saat ini sudah mulai terjerumus ke hal-hal yang bersifat negatif, sehinga banyak ditemukan masalah kekerasan terhadap anak. Terjerumusnya generasi muda ke hal-hal yang bersifat negatif lebih banyak disebabkan oleh adanya salah pergaulan. Berdasarkan hasil pengamatan yang dilakukan oleh peneliti, semakin banyak para generasi muda di desa Mas yang sudah menunjukan karakter kurang baik, hal ini ditunjukan dari kebiasaan-kebiasaan yang dilakukan seperti tidak mau mendengarkan nasehat orang tua, sibuk dengan handphone dan media sosial, kumpulkumpul sambil meneguk minuman keras, bebas berkendaraan masih di bawah umur dan cendrung ikut kebut-kebutan dijalan, bahkan beberapa sudah mulai ke arah pergaulan bebas sehingga ada yang hamil di luar nikah pada usia sekolah.

Permasalahan menurunnya kualitas karakter anak-anak dewasa ini menjadi fenomena kegelisahan yang merebak di tengah masyarakat. Hal ini semakin mengkawatirkan saat teknologi informasi tengah melaju dengan pesat. Degradasi mental dan moral menjadi salah satu pemicu kegelisahan tersebut, disamping faktor-faktor lainnya. Kian maraknya kasus penurunan mental dan moral akhir-akhir ini memberi gambaran belum terpenuhinya tujuan dari pendidikan untuk usaha membuat manusia mempunyai akhlak yang mulia (berkarakter). 
Kegagalan ini diduga terjadi pada tahapan praktis, yang mana pendidikan di sekolah maupun di keluarga yang terjadi selama ini belum sampai pada mendidik anak menjadi berkarakter. Pendidikan yang berkarakter baru hanya sebatas wacana saja, belum mampu menyentuh tatanan moral seorang individu. Kesenjangan yang terjadi pada pengetaahuan moral (cognition) dan perilaku (action), dikarenakan pembelajaran yang sudah berlangsung memiliki orientasi lebih pada intelektual dan tidak diimbangi dengan membentukan mental yang benar dan baik. Hal ini memberi penguatan pada alasan pentingnya diperkuat kembali pendidikan karakter yang mengacu pada kearifan lokal setempat. Pendidikan karakter akan mempunyai makna, saat diberi landasan nilai yang universal yang sudah menjadi akar pada budaya dimana nilai itu dijunjung. Budaya cerdas dibutuhkan untuk menjadikan pendidikan karakter tersebut menjadi semakin kuat dalam penerapan dan kesinambungannya. Kearifan lokal yang nilainya bersifat universal adalah kearifan lokal yang berkonsep pada ajaran Hindu yaitu tri kaya parisudha. Tri kaya parisudha, menyangkut tiga aspek yang harus diperhatikan guna mengendalikan serta menyelaraskan dalam membentuk kualitas manusia diantanya pikiran, perkataan serta perbuatan. Tiga aspek ini sangat penting diperkuat dalam pendidikan anakanak, karena selama ini proses pemebelajaran lebih dominan berorientasi pada pendidikan intelektual. Menurunnya kualitas pendidikan karakter yang lebih banyak menekankan aspek pendidikan teori dan bersifat umum menjadikan ini sebagai sebuah permasalahan yang perlu dilakukan penelitian dengan mencoba mensinergikan kearifan lokal tri kaya parisudha dalam memperkuat aktualisasi tersebut sehingga diharapkan bisa membangun budaya cerdas pada diri anak-anak.

\section{METODE}

Penelitian ini bertempat di sekolah dasar yang ada di desa Mas, Kecamatan Ubud Kabupaten Gianyar. Penelitian ini dilakukan untuk mendapatkan gambaran dan menemukan solusi untuk mengatasi beberapa masalah terkait dengan menurunnya karakter siswa serta mulai memudarnya budaya cerdas dikalangan siswa di sekolah untuk memberi jawaban tantangan di abad 21 dan revolusi industri 4.0. Rancangan pada peneltian ini, mengunakan metode deskriptif kuantitatif dimana data yang didapat dari hasil FGD nantinya akan disimpulkan sehingga mendapatkan hasil yang bisa dijadikan sebagai acuan penerapan ke depannya.

Populasi pada penelitian ini yaitu 300 orang siswa kelas 5 yang tersebar di 9 sekolah dasar yang ada di desa Mas kecamatan Ubud kabupaten Gianyar, terdiri dari 8 sekolah dasar negeri dan 1 sekolah swasta. Dari populasi tersebut, selanjutnya diambil perwakilan yang nantinya akan menjadi kelas eksperimen dan kelas kontrol. Perwakilan yang menjadi kelas eksperimen dan kelas kontrol kemudia disebut sebagai sampel. Jadi, sampel merupakan bagian dari populasi yang secara langsung diteliti (Agung, 2016:8).

Data yang digunakan dalam melakukan uji kesetaraan adalah skor pretest dari kuisoner dalam bentuk sejumlah pernyataan terkait dengan pendidikan karakter yang berbasis nilainilai kearifan lokal tri kaya parisudha pada siswa-siswa SDN 1 Mas, SDN 2 Mas, SDN 3 Mas, SDN 4 Mas, SDN 5 Mas, SDN 6 Mas, SDN 7 Mas, dan SDN 8 Mas. Data tersebut sebelumnya sudah diasumsikan berasal dari populasi yang berdistribusi normal dan memiliki varians yang sama. Hipotesis yang diuji dalam uji kesetaraan dengan uji Anava satu jalur adalah sebagai berikut.

$H_{0}$ :Tidak terdapat perbedaan rerata pada populasi

$$
\left(\mu_{1}=\mu_{2}=\mu_{3}=\mu_{4}=\mu_{5}=\mu_{6}=\ldots=\mu_{12}\right)
$$

$H_{1}$ : Paling tidak ada satu pasang rerata yang tidak sama $\left(\mu_{i} \neq \mu_{j}\right)$

Hasil uji kesetaraan dengan menggunakan uji Anava satu jalur diperoleh nilai signifikansi sebesar $0,009<0,05$, maka $H_{0}$ ditolak sehingga sampel-sampel dari populasi dapat dikatakan paling tidak ada satu pasang rerata yang tidak sama atau tidak homogen. Maka dari itulah perlu dilakukan uji lanjut Anava dengan hasil sebagai berikut: 
Tabel 1. Rekapitulasi Hasil Uji Lanjut Anava

\begin{tabular}{|c|c|c|c|c|}
\hline No & Sekolah & Sekolah & Signifikan & Keterangan \\
\hline \multirow{7}{*}{1} & \multirow{8}{*}{ SDN 1 Mas } & SDN 2 Mas & 0,025 & Tidak Setara \\
\hline & & SDN 3 Mas & 0,000 & Tidak Setara \\
\hline & & SDN 4 Mas & 0,143 & Setara \\
\hline & & SDN 5 Mas & 0,275 & Setara \\
\hline & & SDN 6 Mas & 0,086 & Setara \\
\hline & & SDN 7 Mas & 0,996 & Setara \\
\hline & & SDN 8 Mas & 0,115 & Setara \\
\hline \multirow{6}{*}{2} & & SDN 3 Mas & 0,113 & Setara \\
\hline & \multirow{5}{*}{ SDN 2 Mas } & SDN 4 Mas & 0,356 & Setara \\
\hline & & SDN 5 Mas & 0,316 & Setara \\
\hline & & SDN 6 Mas & 0,611 & Setara \\
\hline & & SDN 7 Mas & 0,091 & Setara \\
\hline & & SDN 8 Mas & 0,563 & Setara \\
\hline \multirow{5}{*}{3} & \multirow{5}{*}{ SDN 3 Mas } & SDN 4 Mas & 0,009 & Tidak Setara \\
\hline & & SDN 5 Mas & 0,013 & Tidak Setara \\
\hline & & SDN 6 Mas & 0,037 & Tidak Setara \\
\hline & & SDN 7 Mas & 0,004 & Tidak Setara \\
\hline & & SDN 8 Mas & 0,035 & Tidak Setara \\
\hline \multirow{4}{*}{4} & \multirow{4}{*}{ SDN 4 Mas } & SDN 5 Mas & 0,840 & Setara \\
\hline & & SDN 6 Mas & 0,708 & Setara \\
\hline & & SDN 7 Mas & 0,285 & Setara \\
\hline & & SDN 8 Mas & 0,787 & Setara \\
\hline \multirow{3}{*}{5} & \multirow{3}{*}{ SDN 5 Mas } & SDN 6 Mas & 0,603 & Setara \\
\hline & & SDN 7 Mas & 0,398 & Setara \\
\hline & & SDN 8 Mas & 0,672 & Setara \\
\hline \multirow{2}{*}{6} & \multirow{2}{*}{ SDN 6 Mas } & SDN 7 Mas & 0,195 & Setara \\
\hline & & SDN 8 Mas & 0,931 & Setara \\
\hline 7 & SDN 7 Mas & SDN 8 Mas & 0,228 & Setara \\
\hline
\end{tabular}

Karena populasi yang digunakan telah diuji kesetaraannya maka sampel diambil sebanyak dua sekolah dari delapan sekolah yang ada secara random. Dari pengundian tersebut diperoleh SDN 5 Mas dan SDN 8 Mas. Dari dua sekolah yang terpilih tersebut diundi kembali untuk menentukan kelompok eksperimen dan kelompok kontrol. Berdasarkan hasil pengundian, terpilih SDN 5 Mas sebagai kelas eksperimen dan SDN 8 Mas sebagai kelompok kontrol.

Metode pengumpulkan data dalam penelitian ini menggunakan metode kuesioner. Kuesioner yang disusun menggunakan model skala Likert. Adapun aspek-aspek pendidikan berbudaya cerdas yang diteliti sebagai rujukan penyusunan kuesioner adalah (1) budaya moral spiritual, (2) budaya bersih rapi, (3) budaya cinta tanah air dan (4) budaya belajar.

Setelah diberikan perlakuan, selanjutnya pengumpulan data tentang budaya cerdas yang dinyatakan oleh skor tes budaya cerdas dari kedua kelompok sampel. Sebelum uji hipotesis dilakukan uji asumsi yaitu uji normalitas sebaran data dan uji homogenitas varians.

Untuk menguji hipotesis, menggunakan uji t dengan taraf sig 0,05 dan persamaan sebagai berikut.

$$
t_{h i t}=\frac{\bar{Y}_{1}-\bar{Y}_{2}}{\sqrt{\frac{s^{2}}{n_{1}}+\frac{s^{2}}{n_{2}}}}
$$




\section{Dengan,}

$$
s^{2}=\frac{\left(n_{1}-1\right) s_{1}^{2}+\left(n_{2}-1\right) s_{2}^{2}}{\left(n_{1}+n_{2}-2\right)}
$$

Keterangan:

(Candiasa, 2010)

$\bar{Y}_{1}$ : Rata - rata skor tes budaya cerdas siswa kelas eksperimen.

$\bar{Y}_{2}$ : Rata - rata skor tes budaya cerdas siswa kelas kontrol.

$s^{2}$ : Varians gabungan

$s_{1}^{2}:$ Varians kelompok eksperimen

$s_{2}^{2}$ : Varians kelompok kontrol

$n_{1}$ : Banyak siswa dari kelompok eksperimen

$n_{2}$ : Banyak siswa dari kelompok kontrol

Nilai $t_{\text {hitung }}$ dibandingkan dengan harga $t_{\text {tabel }}$, dengan taraf sig $5 \%(\alpha=0,05)$ serta derajat kebebasan $\left(n_{1}+n_{2}-2\right)$, apabila nilai $t_{\text {hitung }}>t_{\alpha\left(n_{1}-1, n_{2}-1\right)}$, maka tidak cukup bukti untuk menerima $H_{0}$. Dengan kesimpulan jika budaya cerdas siswa kelas 5 SD N 5 Mas yang ikut sertadalam pembelajaran karakter berbasis kearifan lokal tri kaya parisudha lebih bagus dibandingkan pembelajaran konvensional.

\section{HASIL DAN PEMBAHASAN}

Data mengenai skor yang didapat dari posttest yang diberi pada kelompok eksperimen serta kelompok kontrol, bisa ditinjau pada lampiran 6 berikut ini rangkumannya.

Tabel 2. Rangkuman Analisa Data Skor Pendidikan Berbudaya Cerdas

\begin{tabular}{|c|c|c|c|}
\hline \multirow[b]{2}{*}{ No. } & \multirow{2}{*}{ Variabel } & \multicolumn{2}{|c|}{ Posttest } \\
\hline & & Kelompok Eksperimen & Kelompok Kontrol \\
\hline 1 & Banyak Siswa & 21 & 23 \\
\hline 2 & Rata-rata & 183,05 & 168,17 \\
\hline 3 & Standar Deviasi $(s)$ & 5,971 & 8,473 \\
\hline
\end{tabular}

Mengacu pada Tabel 2, dapat dilihat jika average skor budaya cerdas siswa kelompok eksperimen yang dibelajarkan dengan Pendidikan karakter berbasis kearifan lokal tri kaya parisudha lebih unggul dibandingkan kelompok konvensional.

\section{Pengujian Hipotesis}

Hasil uji normalitas serta uji homogenitas yang sudah dikerjakan memberikan hasil bahwa kelompok eksperimen serta kelompok kontrol memiliki asal yang terdistribusi dengan normal serta juga variannya homogen. Dikarenakan uji prasyarat sudah dipenuhi, maka uji hipotesis bisa dikerjakan melalui uji-t satu ekor guna mengamati ada atau tidak perbedaan budaya cerdas siswa yang dibelajarkan dengan pendidikan karakter berbasis kearifan lokal tri kaya parisudha dan budaya cerdas siswa yang ikut serta kelompok konvensional. Mengacu pada persamaan 1 maka diperoleh:

$H_{0}: \mu_{1}=\mu_{2}$, budaya cerdas siswa adalah sama antara yang dibelajarkan dengan pendidikan karakter berbasis kearifan lokal tri kaya parisudha dan yang dibelajarkan dengan pembelajaran konvensional.

$H_{1}: \mu_{1}>\mu_{2}$, budaya cerdas siswa adalah tidak sama antara yang dibelajarkan dengan pendidikan karakter berbasis kearifan lokal tri kaya parisudha dan yang dibelajarkan dengan pembelajaran konvensional. 
Rangkuman hasil pengujian data budaya cerdas siswa menggunakan Uji-t adalah sebagai berikut:

Tabel 3. Rangkuman Hasil Uji-t Data Budaya Cerdas Siswa

\begin{tabular}{cccccc}
\hline Kelompok & $\mathbf{n}$ & $\bar{X}$ & $t_{\text {hitung }}$ & $t_{\text {tabel }}$ & Signifikan \\
\hline Eksperimen & 21 & 183,05 & 6,671 & 1,681 & \multirow{2}{*}{0,000} \\
Kontrol & 23 & 168,17 & & \\
\hline
\end{tabular}

Mengacu pada hasil perhitungan pada Tabel 3 diatas, didapat jika nilai 6,671> 1,681 dan signifikan $0,000<0,05$, sehingga $H_{0}$ ditolak. Maka dapat disimpulkan, budaya cerdas siswa yang mengikuti pembelajaran dengan pendidikan karakter berbasis kearifan lokal tri kaya parisudha lebih unggul dibandingkan siswa yang mengikuti pembelajaran pembelajaran standar yang lebih pada penekanan secara teori semata dan hapalan (konvensional)..

Berdasarkan hasil Analisa yang sudah dilakukan didapatkan hasil rata-rata skor budaya cerdas siswa pada kelompok eksperimen yaitu 183,05 sedangkan kelompok kontrol yaitu 168,17 . Hasil ini menunjukan bahwa rata-rata skor budaya cerdas siswa pada kelompok eksprimen lebih unggul dibandingkan dengan kelompok kontrol. Dari hasil uji hipotesis menggunakan Uji-t didapatkan, jika signifikan 0,000 $<0,05$ dan nilai $t_{\text {hitung }}=6,671>t_{\text {tabel }}=$ 1,681untuk $\alpha=5 \%$ berarti nilai $H_{0}$ dinilai sebagai penolakan dan $H_{1}$ dinilai sebagai penerimaan. Dengan kata lain, budaya cerdas siswa kelas 5 SD yang ada di desa Mas yang ikut dalam pendidikan karakter berbasis kearifan lokal tri kaya parisudha lebih unggul dari budaya cerdas siswa yang tidak mengikuti sistem sistem pendidikan karakter berbasis kearifan lokal tri kaya parisudha. Hal ini bisa diartikan bahwa pendidikan karakter berbasis kearifan lokal tri kaya parisudha dapat meningkatkan budaya cerdas siswa.

Hal ini terjadi karena pendidikan karakter berbasis kearifan lokal tri kaya parisudha merupakan sebuah model pembelajaran yang dapat mengoptimalkan karakter siswa dengan tiga aspek yang dapat menunjukkan karaktersitik siswa yaitu pikiran, perkataan, serta perbuatan yang benar dan baik dalam proses pembelajaran. Ketiga karakteristik ini perlu dikembangkan dalam meningkatkan potensi yang ada pada siswa untuk mencapai tujuan pembelajaranuntuk mewujudkan budaya cerdas siswa. Berdasarkan ajaran kitab suci Weda, mengajarkan agar umat manusia menjauhkan diri dari kejahatan dan perbuatan dosa serta menyingkirkan kedengkian. Umat manusia agar selalu berbuat dharma atau kebaikan, dengan ucapan yang manis dan selalu berbuat kebaikan. Manusia semestinya juga selalu menyucikan pikiran dan budhinya (Suhardana, 2007: 107). Pernyataan tersebut selaras dengan yang diajarkan dalam ajaran tri kaya parisudha yaitu berpikir baik, berkata baik dan berbuat baik. Berpikir baik, berkata baik dan berbuat baik menjadi dasar dan pedoman hidup bagi umat Hindu dan bagi umat manusia pada umumnya, sehingga kerukunan, ketentraman dan kedamaian dalam kehidupan masyarakat dapat tercipta sesuai dengan tujuan agama Hindu dan tujuan pendidikan pada umumnya. Berkenaan dengan tri kaya parisudha merupakan kearifan lokal yang bersumber pada ajaran Agama Hindu, yang menyangkut tiga aspek tersebut diharapkan berguna untuk membentuk, mengendalikan serta menyelaraskan kualitas manusia dalam pikiran, perkataan serta perbuatan (Hendriana dan Jacobus, 2016).

Nilai yang terkandung pada tri kaya parisudha perlu ditanamkan di lingkungan sekolah, karena sekolah adalah tempat berkembangnya sumber daya insan yang memiliki kecerdasan dan karakter. Oleh karena itu, sangat penting untuk membentuk karakter siswa dari tri kaya parisudha di lingkungan sekolah. Hal ini didukung oleh Puja (1981) yang memberi uraian jika tri kaya parisuddha memiliki beberapa tujuan yakni a) untuk melakukan pengembangan sifat serta sikap yang jujur dan memiliki kesetiaan pada pemikiran, perkataan, dan pebuatan untuk peserta didik dan masyarakat secara umum, b) untuk memberi tumbuh kembang sikap mental yang mempunyai tnggung jawab walau tidak diawasi orang lain, c) untuk melakukan tumbuh kembang kesadaran untuk bersikap baik serta mengenal segala akibat yang bisa muncul dari pikiran, perktaan, serta perbuatan, d) untuk memberikan tuntunan yang baik dan perlu dimiliki juga dijadikan kesadaran pada pergaulan, sehingga bisa memberi penyesuaian diri pada 
lingkungan, e) untuk melakukan pengajaran supaya manusia selalu memiliki kewaspadaan serta hati-hati pada pikiran, perkataan, serta perbuatan. Karena semua hal ini bisa menjadi sumber penyebab ketersinggungan dalam lingkungan kehidupan sosial. Tri kaya parisudha berasal dari tri yang artinya tiga, kaya yang berarti gerak dan parisudha artinya sakral, jadi tri kaya parisudha berarti - tiga karya yang sakral. Ada tiga orang yang tidak bersih untuk dimurnikan, yang berpikir untuk menjadi bersih dan suci (manacika), kata benar (wacika), akan melakukan apa yang lurus (kayika), jadi tri kaya parisudha adalah upaya untuk memurnikan dan membersihkan apa yang kita melakukan (Asmariani, 2012)

Bentuk budaya sekolah timbul menjadi fenomena yang unik juga menarik, dikarenakan pandangan, sikap dan juga perilaku yang hidup dan juga berkembang di sekolah menjadi cerminan kepercayaan dan keyakinan secara mendalam dan khas untuk warga sekolah yang bisa menjadi fungsi untuk memberi semangat membangun karakter pada siswa. Budaya sekolah mencerminkan bagaimana perilaku siswa dalam lingkungan sekolah. Prilaku siswa dipengaruhi oleh karakter siswa masing-masing, sehingga mempengaruhi bagaimana lingkungan sebuah sekolah yang dibangun, mampu menghasilkan budaya sekolah melalui kolaborasi karakter masing-masing siswa. Karakter siswa yang baik dapat menjadikan wadah dalam membangun lingkungan sekolah yang baik, sehingga mawujudkan budaya sekolah yang baik juga, sekaligus berimplikasi pada budaya cerdas siswa. Budaya cerdas pada lingkungan sekolah dapat mewujudkan perlindungan anak yang optimal dalam upaya pembangunan karakter di lingkungan sekolah tersebut. Karakter cerdas pada peserta didik dapat dikembangkan melalui bimbingan dan konseling program perkembangan. Melalui bantuan seorang konselor profesional, peserta didik akan dapat mencapai tugas perkembangan. Serta karakter yang cerdas akan tumbuh dan berkembang secara optimal. Karena layanan bimbingan dan konseling tidak hanya untuk pelajar yang memiliki masalah, tetapi pengembangan layanan bimbingan dan konseling ditujukan untuk semua siswa sehingga mereka dapat mencapai tugas perkembangan dan menjadi orang yang mandiri dan mantap (Mariana, Dewi. 2016).

Pendidikan berbasis karakter kearifan lokal tri kaya parisudha memberikan pedoman siswa dalam pengembangan karakter yang baik (good character) dalam proses pembelajaran (Sudiana \& Sudirgayasa 2015). Pembelajaran dituntut memperhatikan unsur-unsur karakter kearifan lokal tri kaya parisudha yaitu pikiran yang baik dapat mengontrol segala kegiatan yang dilakukan, sehingga dapat meningkatkan berbagai kegiatan yang diperlukan dalam membangun karakter yang baik dan sebaliknya mengurangi kegiatan yang tidak diperlukan. Pembelajaran Quantum Teaching berbasis tri kaya parisudha yaitu manacika (bagaimana berpikir yang bersih dan suci), wacika (berkata yang benar), dan kayika (berbuat yang benar). Dengan metode ini secara komprehensif bisa menumbuhkan karakter siswa itu sendiri, begitu juga metode ini memiliki karakteristik pembelajaran dalam pengembangan kemampuan siswa untuk menemukan pengetahuan itu sendiri serta dapat berpikir, bersikap dan memahami konsep lebih baik (Artawan dan Artiawan,2018).

Pikiran yang baik dapat menghasilkan segala hal yang positif, sehingga karakter baik yang dihasilkan akan membangun karakter yang baik juga dalam lingkungan sekolah. Perkataan yang baik yaitu mengontrol segala ucapan yang muncul dalam proses pembelajaran, sehingga sesuai dengan apa yang diharapkan dalam pembentukan karakter siswa yang baik dalam lingkungan sekolah. Perbuatan yang baik dalam pengembangan diri di lingkungan sekolah. Semua hal tersebut dapat membangun karakter yang diperlukan dalam membangun diri dengan karakter yang baik.

Karakteristik model pendidikan karakter berbasis tri kaya parisudha yang dihasilkan adalah: 1) Model berfokus pada tiga karakter inti, yaitu: berpikir baik (manacika), berkata baik (wacika), dan berbuat baik (manacika), 2) Nilai-nilai karakter yang dikembangakan pada setiap karakter inti berbeda. Pada karakter inti berpikir baik mencakup nilai karakter berpikir positif, nilai religius, dan keyakinan terhadap hukum kasualitas, pada karakter inti berkata baik, mencakup nilai berkata sopan, berkata jujur, sedangkanpada karakter inti berbuat baik mencakup nilai kasih sayang, jujur, peduli linglungan, dan disiplin. Model dilaksanakan secara terintegrasi dalam pembelajaran, 3) Model diimplementasikan dalam pembelajaran melalui habituasi dan keteladanan (Adnyana dan Citrawathi,2017) 
Peran guru dalam penerapan pendidikan karakter berbasis kearifan lokal tri kaya parisudha adalah sebagai fasilitator dalam proses pembelajaran yaitu mulai dari mengenalkan siswa dengan konsep pembelajaran berbasis pikiran yang baik (kayika), perkataan yang baik (wacika) dan perbuatan yang baik (manacika) siswa untuk memahami konsep pembelajaran, sehingga akan tercapai pula optimalisasi budaya cerdas siswa, baik dikalangan siswa berkemampuan tinggi, sedang maupun siswa dengan kemampuan rendah. Keunggulankeunggulan inilah yang membuat pendidikan karakter berbasis kearifanlokal tri kaya parisudha menjadi menarik dan mampu mengakomodir siswa, sehingga mampu mendorong meningkatnya budaya cerdas siswa.

\section{SIMPULAN}

Berdasarkan atas hasil analisis data diperoleh bahwa budaya cerdas siswa yang dibelajarkan dengan pendidikan karakter berbasis kearifan lokal tri kaya parisudha lebih tinggi daripada siswa yang dibelajarkan dengan tanpa pendidikan karakter berbasis kearifan lokal (skor rerata kelompok eksperimen $=183,05$ skor rerata kelompok kontrol $=168,17$ dan $t=$ $6,671)$. Mengacu pada hasil penelitian serta pembahasan di atas, bisa dijelaskan bahwa budaya cerdas siswa kelas 5 SD di desa Mas Kecamatan Ubud Kabupaten Gianyar yang dibelajarkan dengan pendidikan karakter berbasis kearifan lokal tri kaya parisudha lebih unggul dari pada budaya cerdas siswa yang dibelajarkan dengan tanpa pendidikan karakter berbasis kearifan lokal tri kaya parisudha. Sehingga dapat disimpulkan, bahwa pendidikan karakter berbasis kearifan lokal tri kaya parisudha berpengaruh signifikan terhadap budaya cerdas siswa Hasil ini didukung oleh fakta empiris jika siswa yang mengikutipendidikan karakter berbasis kearifan lokal tri kaya parisudha memiliki karakter budaya cerdas yang baik, mampu memotivasi diri, dan mampu mengontrol diri dalam proses pembelajaran sehingga memberi pengaruh pada perwujudan perlindungan anak yang lebih baik.

\section{DAFTAR PUSTAKA}

Adnyana, Putu Budi dan Citrawathi. 2017. Model Pendidikan Karakter Berbasis Tri Kaya Parisudha Terintegrasi dalam Pembelajaran di Sekolah Dasar. Seminar Nasional Riset Inovatif. ISBN: 978-602-6428-11-0

Agung, A. A. Gede. 2016. Statistik Dasar untuk Pendidikan. Yogyakarta: Deepublish

Artawan,Ketut Ngurah dan Ardiawan,I Ketut Ngurah.2018. Pembelajaran Quantum Teaching Berbasis Tri Kaya Parisudha. Edudikara: Jurnal Pendidikan dan Pembelajaran, Vol 3 (2).ISSN 2541-0261 201

Asmariani, A.A. 2012. Tri Kaya Parisudha sebagai Kontrol Sosial Prilaku Remaja dalam Kehidupan Bermasyarakat di Era Globalisasi dan Modernisasi. Sphatika Jurnal Teologi, Vol 6, No 1.

Candiasa, I. M. 2011. Pengujian Instrumen Penelitian disertai Aplikasi ITEMAN dan BIGSTEPS. Singaraja: Universitas Pendidikan Ganesha.

Hendriana, E. C. dan Jacobus, A. 2016. Implementasi Pendidikan Karakter di Sekolah melalui Keteladanan dan Pembiasaan. Jurnal Pendidikan Dasar Indonesia. 1 (2) Page 25 - 29 p-ISSN: 2477-5940 e-ISSN: 2477-8435

Mariana, Dewi. 2016. Membentuk Karakter Cerdas melalui Bimbingan dan Konseling Perkembangan untuk Menghadapi MEA. Jurnal Bimbingan Konseling Indonesia, Volume 1 Nomor 1 Maret 2016. Page 18-22 p=ISSN: 2477-5916

Mulyasa. 2011. Manajemen Pendidikan Karakter. Jakarta: Bumi Aksara.

Puja, G. 1981. Sarasamuscaya. Jakarta: Departemen Agama Republik Indonesia

Sudiana, I. M. dan Sudirgayasa, I G., 2015, Integrasi Kearifan Lokal Bali dalam Buku Ajar Sekolah Dasar 182. Jurnal Kajian Bali. 5 (1). HIm. 181-200 
Volume 11, Nomor 1, Juli, Th. 2020, Hal. 11-20

Suhardana, K. M. 2007. Tri Kaya Parisudha: Bahan Kajian untuk Berpikir Baik, Berkata Baik, dan Berbuat Baik. Surabaya: Paramita. 